\title{
Retreatment Efficacy of Endodontic Bioceramic Sealers: A Review of the Literature
}

\section{Eficacia del retratamiento de cementos endodónticos biocerámicos: Revisión de Literatura}

Flora Kakoura DDS1; Ourania Pantelidou DDS, $\mathrm{PhD}^{2}$

1. Postgraduate student, Department of Endodontology, Faculty of Dentistry, Aristotle University of Thessaloniki, Greece.

2. Professor of Endodontology, Department of Endodontology, Faculty of Dentistry, Aristotle University of Thessaloniki, Greece.

Correspondence to: Dr. Flora Kakoura - kakoura@gmail.com

Received: $18-|| \mid-2018$

Accepted: 26-IV-2018

Published Online First: 2-V-2018

DOl: https://doi.org/10.15517/ijds.v0i0.33163

\section{ABSTRACT}

The endodontic retreatment is a feasible solution when post-operative apical periodontitis persists or develops. The complete removal of the filling materials is important in order to ensure the unobstructed contact of the intracanal disinfectants with the microbes. As a new generation of bioceramic endodontic sealers has emerged, their removal efficacy from the root canal system during retreatment is a matter of concern among clinicians. The aim of this article is to provide a comprehensive review of the current literature on the retreatability of these novel obturating materials. A significant amount of bioceramic sealer remnants in the root canal walls was observed in all studies. Even though canal cleanliness could not be obtained at an ideal level, the re-establishment of the working length and patency can be considered manageable and comparable to other endodontic sealers.

\section{KEYWORDS}

BC Sealer; Bioceramics; BioRoot RCS; Endodontic sealer; iRO0T SP; Retreatment. 


\section{RESUMEN}

El retratamiento endodóntico es una solución factible cuando la periodontitis apical post-operatoria persiste 0 se desarrolla. La eliminación completa de los materiales obturadores es importante para garantizar el contacto y acción de los desinfectantes e irrigantes endodónticos con los microorganismos persistentes. A medida que ha surgido una nueva generación de selladores endodónticos biocerámicos, su eficacia de eliminación del sistema de conductos radiculares durante el retratamiento es motivo de preocupación entre los profesionales. El objetivo de este artículo es proporcionar una revisión exhaustiva de la literatura actual sobre la influencia o posibles limitantes del uso de este tipo de cementos bioactivos durante el retratamiento endodóntico. Los estudios determinaron una cantidad significativa de restos de selladores biocerámicos en las paredes del conducto radicular. Aunque la limpieza del canal no se pudo obtener a un nivel "ideal", el restablecimiento de la longitud de trabajo y la permeabilidad se puede considerar manejable y comparable a otros selladores endodónticos.

\section{PALABRAS CLAVE}

BC Sealer; Biocerámicos; BioRoot RCS; Cemento obturador endodóntico; iROOT SP; Retratamiento.

\section{INTRODUCTION}

Primary root canal therapy is a predictable medical procedure with a minimum success rate of $82 \%$ for vital and $73 \%$ for non-vital teeth $(1,2)$. However, the endodontic treatment may not be successful due to various reasons. The inadequate chemomechanical debriment results to remaining contaminated pulpal tissue. Moreover, recurrent carries, tooth fracture or unsuccessful coronal restoration may facilitate the re-establishment of bacterial biofilms and hinder the survival of the tooth $(3,4)$. In cases where an endodontic inflammatory lesion persists or develops, the options of endodontic retreatment, surgical intervention or tooth extraction may be considered (5). It has been shown that the success rate of the former option is $77 \%$ (6). Thus, when possible, orthograte root canal retreatment should be the first choice of the clinician, as it may provide an environment conducive to periradicular healing without rendering the tooth structure (7).

The main aim during the revision of a root canal therapy is the elimination of the microorganisms and their by-products that sustain the periapical pathosis (8). The remaining obturating materials operate as a mechanical barrier between the intracanal disinfectants and the microbes that reside in areas hard to access such as dentinal tubules, lateral canals and isthmi (9). Hence, in order to allow irrigants and medicaments to reach every part of the root canal system, all the filling remnants should be removed $(10,11)$. Furthermore, the apical retrieval of the obturating materials during re-instrumentation assists the clinician to attain apical patency (12). Also, the residual material may adversely affect the adhesion of the new sealer to dentin (13). It has been demonstrated that most of the remnants after retreatment are of sealer origin (14). Unfortunately, several reports argue that its complete removal cannot be achieved with any known retreatment method (15-20).

Since its introduction as "Hill's stopping", gutta percha is the most common material for root canal obturation. Gutta percha is used in conjunction with a root canal sealer (21). Depending on their chemical formulation, sealers can be classified as zinc-oxide eugenol, epoxy resin, silicon, calcium hydroxide, glass ionomer, methaacrylate resin, and calcium-silicate based. The latter category includes the MTA and the 
bioceramic based sealers (21-23). The second generation bioceramic sealers are made of pure medical-grade tricalcium silicate nanoparticles, do not include an aluminate phase and are free of heavy metals $(24,25)$.

The controversy on the removal of the bioceramic root canal sealers during retreatment is a matter of concern among clinicians. Thus, the aim of this study was to assess their retreatability by identifying the published research and by performing a comparative analysis of the results. To the best of our knowledge this is the first review highlighting this issue.

In order to collect the available literature, a search for citations up to February 2018, was undertaken using the Embase and the Medline databases. The keywords used for the search were: "Bioceramic sealer removal", "Bioceramic sealer retreatment", "BioRoot RCS", "Endosequence BC Sealer", "iROOT SP", "Totalfill BC sealer" and "Tricalcium silicate sealer". The search was restricted to English language articles.

\section{THE MODEL OF BONDING BETWEEN BIOCERAMICS AND DENTIN}

The first pure bioceramic endodontic sealer was launched in 2007 as iROOT SP (Innovative BioCeramix, Inc., Vancouver, Canada). This sealer is also on the market under the name EndoSequence BC Sealer (Brasseler USA, Savannah, Georgia) and Totalfill BC Sealer (FKG Dentaire, Switzerland) $(25,26)$. Present in its chemical composition are calcium silicate, calcium phosphate monobasic, zirconium oxide, filler and thickening agents (27). Recently, another high purity bioceramic sealer, BioRoot RCS (Septodont, Saint Maur des Fossés, France) was launched. Modified from Biodentine, its fine powder consists of tricalcium silicate and zirconium oxide, while the liquid solution contains calcium chloride. Both parts comprise excipients as well (28).
Similar to other calcium silicate based sealers, bioceramics utilize the inherent moisture of the dentinal tubules in order to set. The hydration reaction results in the formation of a calcium silicate hydrate gel and portlandite (29). The latter reacts with the phosphate-ion containing dentinal fluid and forms hydroxyapatite, that in the supersaturated alkaline environment appears as calcium-deficient B-type carbonated apatite precipitate $(30,31)$. The deposition of apatite crystals confirms the bioactivity of these materials (32).

The way bioceramic sealers bond to root dentin after setting is under investigation $(27,33)$. Research suggests a chemical adherence (34) as well as a micromechanical anchorage of the material to the dentin substrate (27). Specifically, the setting reaction products cause an alkaline caustic etching to the adjacent dentin that ruptures the intermolecular bonds of the collagen fibrils and creates a porous surface. In this zone, an ion exchange layer is formed and minerals of the sealer permeate the dentin (35). This zone is called the mineral infiltration zone $(27,31,35)$. Along this layer, intrafibrillar apatite deposition takes place (36). Moreover, in vitro studies illustrated intratubular diffusion of the calcium silicate minerals, that appear as mineral plugs, and extend from the interfacial layer to within the dentinal tulules $(31,34,35,37,38)$. The tubular penetration of BioRoot RCS was confirmed in a study, as confocal microscopy revealed mineral tags along the mineral infiltration zone and inside the dentin. This zone was absent in the AH Plus group, which however exhibited resin tags within the dentinal tubules (39). The extent of tubule penetration for calcium silicate based sealers was

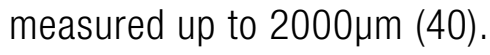

Regarding the above, it can be speculated that the chemical bond, induced by the interactions in the mineral infiltration zone and by the precipitation of apatite crystals, and the micromechanical anchorage, caused by the cement 
plugs in the dentinal tubules, create a unique model of bonding between the calcium silicate materials and the dentin.

This biomineralization activity has been shown to enhance the adhesion and the resistance to dislocation from dentin $(41,42)$. The aforementioned property, as well as their hardness upon setting $(19,43)$, may hinder the complete subtraction of these sealers from the root canal during the secondary endodontic treatment. Thirteen in vitro studies that referred to the removal of the calcium silicate obturating materials were located and selected for this review $(19,33,43-$ 52). Two of those were excluded because they were referring to calcium silicate sealers that were MTA-based $(47,48)$. From the remaining eleven studies, six evaluated the retreatability of Endosequence BC Sealer (19,44,46,50-52), three of iROOT SP $(45,49,53)$, one of Totalfill BC sealer (43) and one of BioRoot RCS (33) (Table 1).

\section{RETREATABILITY ASSESSMENT METHODS AND TECHNIQUES}

In order to evaluate the retreatability of the bioceramic sealers, the studies considered various parameters (Table 1). For example, the ability to reach working length $(\mathrm{WL})(43,44)$ and the attain of patency $(19,33,43,44,50-52)$ were assessed. The time to reach working length $(45,49,53)$ or to complete the retreatment procedure $(19,33,43-$ $45,50,53)$ were also recorded. The material remnants were evaluated with various techniques such as digital radiography (46), scanning electron microscopy $(44,50,53)$, confocal microscopy $(50)$, micro CT $(19,45,51,52)$ and optical microscopy $(33,43,49)$. The techniques that were used present some advantages and entail some limitations. The radiographs and digital images of vertically sectioned teeth offer two dimensional information about a three dimensional space and no accurate measurement of the total canal area can be implemented. Another shortcoming is the subjective evaluation of the remaining material that can occur between observers. Moreover, part of the filling remnants can be dislocated during the root splitting $(19,45,49)$. On the other hand, scanning electron microscopy can qualitatively assess the cleanliness of the open or obstructed dentinal tubules (53). Micro CT is a non-invasive and reproducible evaluation method that can quantitatively measure the remaining debris with limited operator bias (19). However it cannot distinguish the proportion of gutta percha and sealer remnants (45). Also, the evaluation of the thickness and the depth of sealer penetration into dentinal tubules may be accurately depicted only with confocal microscopy (50). 
Table 1: Studies referring to the retreatability of the bioceramic sealers.

\begin{tabular}{|c|c|c|c|}
\hline STUDY & NUMBER OF SPECIMENS & SEALERS & EVALUATION METHODS \\
\hline Hess et al. 2011 (44) & $\begin{array}{l}40 \text { mesial buccal roots } \\
\text { of upper molars }\end{array}$ & $\begin{array}{c}\text { AH Plus } \\
\text { Endosequence BC Sealer }\end{array}$ & $\begin{array}{c}\text { Scanning electron microscopy } \\
\text { Working length } \\
\text { Patency } \\
\text { Time for retreatment }\end{array}$ \\
\hline Ersev et al. 2012 (46) & $\begin{array}{l}120 \text { palatal roots } \\
\text { of upper molars }\end{array}$ & $\begin{array}{c}\text { Activ GP System } \\
\text { AH Plus } \\
\text { Endosequence BC Sealer } \\
\text { Hybrid Root SEAL }\end{array}$ & Digital X-Ray \\
\hline Ma et al. 2012 (45) & 40 lower incisors & iRoot SP & $\begin{array}{c}\text { micro-CT } \\
\text { Time for retreatment }\end{array}$ \\
\hline Simsek et al. 2014 (53) & 60 single-rooted premolars & $\begin{array}{l}\text { AH Plus, } \\
\text { iRoot SP } \\
\text { MM Seal }\end{array}$ & $\begin{array}{l}\text { Scanning electron microscopy } \\
\text { Time for retreatment }\end{array}$ \\
\hline Uzunoglu et al. 2015 (49) & 40 lower premolars & $\begin{array}{c}\text { AH-26 } \\
\text { iRooT SP } \\
\text { MTA Fillapex }\end{array}$ & $\begin{array}{l}\text { Stereomicroscopy } \\
\text { Time for retreatment }\end{array}$ \\
\hline Kim et al. 2015 (50) & 28 single-rooted teeth & $\begin{array}{c}\text { AH Plus } \\
\text { EndoSequence BC Sealer }\end{array}$ & $\begin{array}{c}\text { Scanning electron microscopy } \\
\text { Confocal microscopy } \\
\text { Patency } \\
\text { Time for retreatment }\end{array}$ \\
\hline Agrafioti el al. 2015 (43) & 54 single-rooted teeth & $\begin{array}{c}\text { AH Plus } \\
\text { MTA Fillapex } \\
\text { TotalFill BC Sealer }\end{array}$ & $\begin{array}{l}\text { Optical microscopy } \\
\text { Working length } \\
\text { Patency } \\
\text { Time for retreatment }\end{array}$ \\
\hline $\begin{array}{l}\text { de Siqueira Zuolo et al. } 2016 \\
\text { (19) }\end{array}$ & 64 lower canines & $\begin{array}{l}\text { Endosequence BC Sealer } \\
\text { Pulp Canal Sealer EWT }\end{array}$ & $\begin{array}{c}\text { Micro-CT } \\
\text { Patency } \\
\text { Time for retreatment }\end{array}$ \\
\hline Oltra et al. 2016 (51) & 56 upper incisors & $\begin{array}{c}\text { AH Plus } \\
\text { Endosequence BC Sealer }\end{array}$ & $\begin{array}{l}\text { Micro-CT } \\
\text { Patency }\end{array}$ \\
\hline Donnermeyer et al. 2017 (33) & 192 single-rooted teeth & $\begin{array}{l}\text { AH Plus } \\
\text { BioRoot RCS } \\
\text { Endo C.P.M } \\
\text { MTA Fillapex }\end{array}$ & $\begin{array}{l}\text { Light microscopy } \\
\text { Patency } \\
\text { Time for retreatment }\end{array}$ \\
\hline Suk et al. 2017 (52) & $\begin{array}{l}36 \text { upper lateral incisors } \\
\text { and lower premolars }\end{array}$ & $\begin{array}{c}\text { AH Plus } \\
\text { Endosequence BC Sealer } \\
\text { MTA Fillapex }\end{array}$ & $\begin{array}{l}\text { Micro-CT } \\
\text { Patency }\end{array}$ \\
\hline
\end{tabular}


THE EFFECT OF THE OBTURATING MATERIALS AND TECHNIQUES

In all experiments the main filling material was gutta percha. However, the obturation modality differed among studies. Roots were filled either with lateral compaction $(45,49,52,53)$, continuous wave of condensation $(19,43-45,50,51)$ or single cone technique $(33,44,46,49)$. Ma et al. used iRoot SP either with lateral or warm vertical compaction of gutta percha. It was proved that there were statistically more filling remnants in the apical portion of the root canal after retreatment when the second obturation technique was used (45). Moreover, two studies examined the retreatability when the master cone was intentionally placed 2 $\mathrm{mm}$ above the working length during obturation $(43,44)$. In Hess et al. the WL was reached only in $30 \%$ of the teeth obturated with Endosequence BC Sealer and misplaced gutta percha. These findings come in contrast to Agrafioti et al., who followed the same obturation protocol, and the WL was reached in $100 \%$ of the specimens filled with TotalFill BC Sealer. The authors attribute the different results to the unlike class of teeth that were used in the two studies (43). It should be noted that, although Agrafioti et al. used warm vertical compaction for all specimens, Hess et al. used this technique only for AH Plus and the bioceramic sealer was used in a single cone technique. Hence it can be speculated that the different obturation techniques may alter the results among studies. Furthermore, in the first study chloroform was used as a solvent.

\section{THE EFFECT OF THE RETREATMENT TECHNIQUES}

Various retreatment techniques are presented in the studies. Ultrasound tips (43), Gates Glidden drills $(19,46,50,53)$ and heat application (44) were employed for the removal of the coronal filling material. Their additional use might affected the results of the studies that compared the dentinal cleanliness among different root canal thirds after the bioceramic sealer removal $(46,53)$. Specifically, the use of Gates Glidden drills $(46,53)$ and ultrasound tips (53) in the coronal part of the root may enhanced the result of more clogged dentinal tubules (53) and more remaining debris (46) in the apical third. On the contrary, when the canals were instrumented only with rotary files, the percentage of the residual bioceramic sealer on the apical third was similar (49) or less (51) from the middle and the coronal third.

Rotary $(19,33,43-46,49-53)$ and hand $(33,46,49)$ files were used along with sodium hypochloride (19,33,43-46,49-53) and EDTA $(19,33,45,51-53)$ for the removal of the filling material. Although most studies utilized one sequence of rotary files for all specimes (4345,49-52), some compared the bioceramic material removal efficacy of a rotary system to another $(19,33)$ or to Hedström files $(33,46)$. Donnermeyer et al. found the manual removal of BioRoot RCS to be as effective as the removal with various rotary systems (Reciproc R40, Mtwo 40/.06, F6 Skytaper). In the same study the sealer remnants did not differ statistically between the rotary systems either (33). Similarly, the Protaper Universal retreatment system and the manual Hedström files were found equally effective in the removal of Endosequence BC Sealer (46). This comes in accordance with de Siquera Zuolo et al. who found no difference in the volume of the remaining Endosequence BC Sealer when comparing the TRUShape and Reciproc file systems (19). Furthermore, the residual debris of iRoot SP was evaluated after retreatment with ultrasound ESI tips or a rotary system (R-Endo files). There was no difference in the amount of filling material between the techniques (53). The effect of the Photon Induced Photoacoustic Streaming (PIPS) was also assessed in a study. The PIPS significantly enhanced the dislocation of 
the Endosequence BC Sealer remnants from the root canal after retreatment (52).

\section{THE EFFECT OF SOLVENTS DURING RETREATMENT}

Some studies tested the dissolving capacity of chloroform in all $(19,43,44)$ or in half $(45,51)$ of their specimens. One study mentioned that chloroform solvents do not improve the removal of the Endosequence BC Sealer (43). Additionally, chloroform delayed the removal of iRooT SP from the root canal (45). On the contrary, Oltra et al. found that the use of chloroform reduced significantly the residual Endosequence BC Sealer remnants (51).

\section{COMPARISON AMONG SEALERS}

The bioceramic sealer remnants were compared to those of AH Plus (33,46,50-53), $\mathrm{AH}$ 26 (49), MTA Fillapex $(33,49,52)$, Hybrid Root Seal (46), Activ GP System (46), MM Seal (53), Pulp Canal Sealer EWT (19) and Endo C.P.M sealer (33). The retreatment procedure was considered to be complete when filling debris was no longer evident on the endodontic files. However, all of the studies had concluded that a significant amount of filling materials remained in the root canal after the retreatment. This result referred not only to the bioceramic but also to all the other endodontic sealers (19,33,46,49-53). Particularly, retreatment of iRoot SP left more filling remnants than AH-26 (49). When Endosequence BC Sealer was compared with Hybrid Root SEAL and Activ GP, no significant difference was detected with respect to the material oddments (46). The same results were demonstrated for iRoot SP - MM Seal (53) and BioRoot RCS - Endo CPM Sealer (33). However, specimens filled with Endosequence BC Sealer had significantly more remnants than those filled with Pulp Canal Sealer EWT (19). Regarding AH Plus, it exhibited the same $(46,50,52,53)$ or less $(51)$ remaining filling material than Endosequence $B C$ Sealer and iRoot SP. On the contrary, retreatment of BioRoot RCS resulted in less sealer remnants than AH Plus (33). It should be also mentioned that $6 \mathrm{~mm}$ beyond the apex confocal microscopy revealed the same amount of dentin penetration area and a deeper penetration depth for AH Plus when compared to Endosequence BC Sealer (50). Furthermore, while Suk et al. found the residual debris of MTA Fillapex to be significantly less than Endosequence BC Sealer (52), two studies contend that this sealer leaves the same amount of remnants as iRoot SP (49) and BioRoot RCS (33). The discrepancy of the results may be attributed to differences in methodology, such as the use of teeth with different root canal anatomy, the different retreatment methods, and to the different assessment of the remaining filling material (46). Thus, firm conclusions are not feasible.

\section{THE ABILITY TO REACH WORKING LENGTH AND TO} ATTAIN PATENCY

The ability to reach working length was examined by three studies $(43,44,51)$. Hess et al. compared the retreatability of $\mathrm{AH}$ Plus and Endosequence BC Sealer with the master cone placed to or $2 \mathrm{~mm}$ short of the working length. The WL attainment of the 'Endosequence BC Sealer - master cone $2 \mathrm{~mm}$ short of the WL group was significantly lower from all the other groups (44). On the contrary Agrafioti et al. presents different results. They compared the retreatability of TotalFill BC Sealer, AH Plus and MTA Fillapex, with the gutta percha cone placed as described above. WL was achieved in all specimens of all groups (43). Regardless of the use of chloroform as a solvent, Oltra et al. showed a 93\% recovery of WL in the specimens filled with Endosequence BC Sealer (51).

The establishment of patency has been reported to significantly increase the periradicular healing rates (54). Hence, the attain of patency was thoroughly investigated and regained by small stainless steel hand files $(19,33,43,44,50-52)$. 
In three studies patency was achieved in all of the specimens filled with bioceramic sealer and gutta percha $(33,43,50)$. On the contrary, while the apical foramen was accessed in all teeth obturated with Pulp Canal Sealer EWT, this was not feasible for $15 \%$ of the specimens obturated with Endosequence BC Sealer (19). Hess et al. mentioned a $30 \%$ to $80 \%$ apical patency recovery depending on the placement of gutta percha $2 \mathrm{~mm}$ short of or to the WL (44). In another study, the retreatment of Endosequence BC Sealer without or with the use of chloroform led to a $14 \%$ and $80 \%$ patency regaining respectively (51). Hence, it can be speculated that access to the apical foramen is feasible after a root canal filling with bioceramic sealer, especially when the gutta percha cone had reached the working length during the initial obturation.

\section{THE RETREATMENT TIME}

The time to reach working length $(45,49,53)$ or to complete the retreatment procedure $(19,33,43-$ $45,50,53)$ was also recorded. According to Hess et al. the time for retreatment of Endosequence BCS was significantly longer than AH Plus (44) and Pulp Canal Sealer EWT (19), but Kim et al. did not confirm the former difference (50). The removal of iRooT SP was similar in seconds to MM Seal, $\mathrm{AH}$ Plus (53) and AH-26, but longer than MTA Fillapex (49). Nevertheless, the use of solvent delayed its retreatment procedure (45). Likewise, Agrafioti et al. found that the retreatment of AH Plus was faster than TotalFill BC Sealer (43). Finally, the removal of BioRoot RCS with Hedström files was significantly faster than AH Plus and same as MTA Fillapex and Endo CPM sealer (33). The different obturation and retreatment methods that were used among the studies may be responsible for the variance of the results. However, even when the removal of the bioceramic sealer demanded more time, the retreatment procedure was successful in most of the cases.

\section{CONCLUSION}

All studies have concluded that despite the fact that filling debris was not evident on the endodontic files after the retreatment procedure, a significant amount of filling materials still remained in the root canal. This was a matter of fact not only for the bioceramic but also for all the other endodontic sealers. The attainment of working length and patency was achievable at a satisfying level. Thus, the retreatability of these novel calcium silicate sealers can be considered manageable in the clinical act.

\section{REFERENCES}

1. Kojima K., Inamoto K., Nagamatsu K., Hara A., Nakata K., Morita I., et al. Success rate of endodontic treatment of teeth with vital and nonvital pulps. a meta-analysis. Oral Surg Oral Med Oral Pathol Oral Radiol Endod. 2004; 97 (1): 95-9.

2. Ng Y-L., Mann V., Rahbaran S., Lewsey J., Gulabivala K. Outcome of primary root canal treatment: Systematic review of the literaturePart 2. Influence of clinical factors. Int Endod J. 2008; 41 (1): 6-31.

3. Haapasalo M., Shen Y., Qian W., Gao Y. Irrigation in Endodontics. Dent Clin North Am. 2010; 54 (2): 291-312.

4. Nair PNR. On the causes of persistent apical periodontitis: A review. Int Endod J. 2006; 39 (4): 249-81. 
5. Trope M. The vital tooth - its importance in the study and practice of endodontics. Endod Top. 2003; 5 (1): 1-1.

6. Ng Y-L., Mann V., Gulabivala K. Outcome of secondary root canal treatment: a systematic review of the literature. Int Endod J. 2008; 41 (12): 1026-46.

7. Zehnder M., Paque F. Disinfection of the root canal system during root canal. Endod Top. 2011; (9): 58-73.

8. Nair P. N. R. Pathogenesis of Apical Periodontitis and the Causes of Endodontic Failures. Crit Rev Oral Biol Med. 2004; 15 (6): 348-81.

9. Schirrmeister J. F., Wrbas K. T., Meyer K. M., Altenburger M. J., Hellwig E. Efficacy of Different Rotary Instruments for GuttaPercha Removal in Root Canal Retreatment. J Endod. 2006; 32 (5): 469-72.

10. Grischke J., Muller-Heine A., Hulsmann M. The effect of four different irrigation systems in the removal of a root canal sealer. Clin Oral Investig. 2013; 1-7.

11. Ring J., Murray P. E., Namerow K. N., Moldauer B. I., Garcia-Godoy F. Removing Root Canal Obturation Materials A Comparison of Rotary File Systems and Retreatment Agents. J Am Dent Assoc. 2009; 140 (6): 680-8.

12. Hülsmann M., Bluhm V. Efficacy, cleaning ability and safety of different rotary NiTi instruments in root canal retreatment. Int Endod J. 2004; 37 (7): 468-76.

13. Rached-Junior F. J. A., Sousa-Neto M. D., Souza-Gabriel A. E., Duarte M. A. H., Silva-
Sousa Y. T. C. Impact of remaining zinc oxide-eugenol-based sealer on the bond strength of a resinous sealer to dentine after root canal retreatment. Int Endod J. 2014; 47 (5): 463-9.

14. Wilcox L. R., Krell K. V., Madison S., Rittman B. Endodontic retreatment: Evaluation of gutta-percha and sealer removal and canal reinstrumentation. J Endod. 1987; 13 (9): 453-7.

15. Ruddle C. Nonsurgical Retreatment. J Endod. 2004; 30 (12): 827-45.

16. Taşdemir T., Er K., Yildirim T., Çelik D. Efficacy of three rotary NiTi instruments in removing gutta-percha from root canals. Int Endod J. 2008; 41 (3):191-6.

17. Duncan H. F., Chong B. S. Removal of root filling materials. Endod Top. 2008; 19 (1): 33-57.

18. Rödig T., Reicherts P., Konietschke F., Dullin C., Hahn W., Hülsmann M. Efficacy of reciprocating and rotary NiTi instruments for retreatment of curved root canals assessed by micro-CT. Int Endod J. 2014; 47 (10): 942-8.

19. De Siqueira Zuolo A., Zuolo M. L., Da Silveira Bueno C. E., Chu R., Cunha R. S. Evaluation of the Efficacy of TRUShape and Reciproc File Systems in the Removal of Root Filling Material: An Ex Vivo MicroComputed Tomographic Study. J Endod. 2016; 42 (2): 315-9.

20. Rödig T., Kupis J., Konietschke F., Dullin C., Drebenstedt S., Hülsmann M. Comparison of hand and rotary instrumentation for removing gutta-percha from previously treated curved 
root canals: A microcomputed tomography study. Int Endod J. 2014; 47 (2): 173-82.

21. Prakash R., Gopikrishna V., Kandaswamy D., Student P., and P. Gutta-percha - An untold story. Endodontology. 2005; 17 (2): 32-6.

22. Singh H., Markan S., Kaur M., Gupta G., Singh H., Kaur M. S., et al. Endodontic Sealers : Current Concepts and Comparative Analysis. Dent Open J. 2015; 2 (1): 32-7.

23. Ørstavik D. Materials used for root canal obturation : technical, biological and clinical testing. Endod Top. 2005; 12 (3): 25-38.

24. Tyagi S., Tyagi P., Mishra P. Evolution of root canal sealers: An insight story. Eur J Gen Dent. 2013; 2 (3): 199.

25. Camilleri J. Is Mineral Trioxide Aggregate a Bioceramic?. Odovtos - International Journal of Dental Sciences, [S.1.], v. 18, n. 1, p. 13-17, mar. 2016. doi:http://dx.doi.org/10.15517/ ijds.v18i1.23482.

26. Debelian G., Trope M. The use of premixed bioceramic materials in endodontics. G Ital Endod. 2016; 30 (2): 70-80.

27. Trope M., Bunes A., Debelian G. Root filling materials and techniques : bioceramics a new hope ? Endod Top. 2015; 86-96.

28. Al-Haddad A., Aziz ZACA. BioceramicBased Root Canal Sealers: A Review. Int J Biomater. 2016; 2016:9753210.

29. Eldeniz A. U., Shehata M., Högg C., Reichl FX. DNA double-strand breaks caused by new and contemporary endodontic sealers. Int Endod J. 2016; 49 (12): 1141-51.

30. Malhotra S. Bioceramic Technology in Endodontics. Br J Med Med Res. 2014; 4 (12): 2446-54.

31. Tay F. R., Pashley D. H., Rueggeberg F. A., Loushine R. J., Weller R. N. Calcium Phosphate Phase Transformation Produced by the Interaction of the Portland Cement Component of White Mineral Trioxide Aggregate with a Phosphate-containing Fluid. J Endod. 2007; 33 (11): 1347-51.
32. Han L., Okiji T. Uptake of calcium and silicon released from calcium silicate-based endodontic materials into root canal dentine. Int Endod J. 2011; 44 (12): 1081-7.

33. Arias-Moliz M. T., Camilleri J. The effect of the final irrigant on the antimicrobial activity of root canal sealers. J Dent. 2016; 52: 30-6.

34. Donnermeyer D., Bunne C., Schäfer E., Dammaschke T. Retreatability of three calcium silicate-containing sealers and one epoxy resin-based root canal sealer with four different root canal instruments. Clin Oral Investig. 2018; 22 (2): 811-817.

35. SarkarN.K., Caicedo R., Ritwik P., Moiseyeva R., Kawashima I. Physicochemical basis of the biologic properties of mineral trioxide aggregate. J Endod. 2005; 31 (2): 97-100.

36. Atmeh A. R., Chong E. Z., Richard G., Festy F., Watson T. F. Dentin-cement Interfacial Interaction: Calcium Silicates and Polyalkenoates. J Dent Res. 2012; 91 (5): 454-9.

37. Zhang H., Shen Y., Ruse N. D., Haapasalo M. Antibacterial Activity of Endodontic Sealers by Modified Direct Contact Test Against Enterococcus faecalis. J Endod. 2009; 35 (7): 1051-5.

38. Zhang W., Li Z., Peng B. Assessment of a new root canal sealer's apical sealing ability. Oral Surg Oral Med Oral Pathol Oral Radiol Endod. 2009; 107 (6): 79-82.

39. Reyes-Carmona J. F., Felippe M. S., Felippe W. T. A phosphate-buffered saline intracanal dressing improves the biomineralization ability of mineral trioxide aggregate apical plugs. J Endod. 2010; 36 (10): 1648-52.

40. Viapiana R., Moinzadeh A. T., Camilleri L., Wesselink P. R., Tanomaru Filho M., Camilleri J. Porosity and sealing ability of root fillings with gutta-percha and BioRoot RCS or AH Plus sealers. Evaluation by three ex vivo methods. Int Endod J. 2016; 49 (8): 774-82. 
41. McMichael G. E., Primus C. M., Opperman L.A. Dentinal tubule penetration of tricalcium silicate sealers. J Endod. 2016; 42 (4): 632-6.

42. Reyes-Carmona J. F., Felippe M. S., Felippe W. T. The Biomineralization Ability of Mineral Trioxide Aggregate and Portland Cement on Dentin Enhances the Push-out Strength. J Endod. 2010; 36 (2): 286-91.

43. Nagas E., Uyanik M. O., Eymirli A., Cehreli Z. C., Vallittu P. K., Lassila L. V. J., et al. Dentin moisture conditions affect the adhesion of root canal sealers. J Endod. 2012; 38 (2): 240-4.

44. Agrafioti A., Koursoumis A. D., Kontakiotis E. G. Re-establishing apical patency after obturation with Gutta-percha and two novel calcium silicate-based sealers. Eur J Dent. 2015; 9 (4): 457-61.

45. Hess D., Solomon E., Spears R., He J. Retreatability of a bioceramic root canal sealing material. J Endod. 2011; 37 (11): 1547-9.

46. Ma J., Al-Ashaw A. J., Shen Y., Gao Y., Yang Y., Zhang C., et al. Efficacy of ProTaper universal rotary retreatment system for guttapercha removal from oval root canals: A micro-computed tomography study. J Endod. 2012; 38 (11): 1516-20.

47. Ersev H., Yilmaz B., Dinçol M. E., Dağlaroğlu R. The efficacy of ProTaper Universal rotary retreatment instrumentation to remove single gutta-percha cones cemented with several endodontic sealers. Int Endod J. 2012; 45 (8): 756-62.

48. Neelakantan P., Grotra D., Sharma S. Retreatability of 2 mineral trioxide aggregatebased root canal sealers: A cone-beam computed tomography analysis. J Endod. 2013; 39 (7): 893-6.

49. Carpenter M. T., Sidow S. J., Lindsey K. W., Chuang A., McPherson J. C. Regaining apical patency after obturation with gutta-percha and a sealer containing mineral trioxide aggregate. J Endod. 2014; 40 (4): 588-90.
50. Uzunoglu E., Yilmaz Z., Sungur D. D., Altundasar E. Retreatability of root canals obturated using gutta-percha with bioceramic, MTA and resin-based sealers. Iran Endod J. 2015; 10 (2): 93-8.

51. Kim H., Kim E., Lee S. J., Shin S. J. Comparisons of the Retreatment Efficacy of Calcium Silicate and Epoxy Resin-based Sealers and Residual Sealer in Dentinal Tubules. J Endod. 2015; 41 (12): 2025-30.

52. Oltra E., Cox T. C., LaCourse M. R., Johnson J. D., Paranjpe A. Retreatability of two endodontic sealers, EndoSequence BC Sealer and AH Plus: a micro-computed tomographic comparison. Restor Dent Endod. 2017; 42 (1): 19-26.

53. Suk M., Bago I., Katić M., Šnjarić D., Munitić MŠ, Anić I. The efficacy of photon-initiated photoacoustic streaming in the removal of calcium silicate-based filling remnants from the root canal after rotary retreatment. Lasers Med Sci. 2017; 32 (9): 2055-2062.

54. Simsek N., Keles A., Ahmetoglu F., Ocak M. S., Yologlu S., Simsek N., et al. Comparison of different retreatment techniques and root canal sealers: a scanning electron microscopic study. Braz Oral Res 2014; 28 (1):1-7.

55. TotalFill BC Sealer, Intsructions for use, [PDF on Internet], Available from: http://www.fkg. $\mathrm{ch} / \mathrm{sites} /$ default/files/201511_Totalfill_BC_ Sealer_ifu_xx.pdf

56. Endosequence BC Sealer, Instructions for use, [PDF on Internet], Available from: http:// brasselerusadental.com/wp-content/files/B3114D-EndoSequence-BC-Sealer-DFU.pdf

57. BioRoot RCS, Instructions for use, [PDF on Internet], Available from: http:// www.septodontusa.com/sites/default/ files/2016-03/BioRoot-IFU_0.pdf

58. Khalil I., Naaman A., Camilleri J. Properties of Tricalcium Silicate Sealers. J Endod. 2016; 42 (10): 1529-35.

59. Prüllage R. K., Urban K., Schäfer E., Dammaschke T. Material Properties of a 
Tricalcium Silicate-containing, a Mineral Trioxide Aggregate-containing, and an Epoxy Resin-based Root Canal Sealer. J Endod. 2016; 42 (12): 1784-8.

60. Siboni F., Taddei P., Zamparini F., Prati C., Gandolfi MG. Properties of BioRoot RCS, a tricalcium silicate endodontic sealer modified with povidone and polycarboxylate. Int Endod J. 2017; 50 (2): 120-136.

61. Loushine B. A., Bryan T. E., Looney S. W., Gillen B. M., Loushine R. J., Weller R. N., et al. Setting properties and cytotoxicity evaluation of a premixed bioceramic root canal sealer. J Endod. 2011; 37 (5): 673-7.

62. Qu W., Bai W., Liang Y.H., Gao X. J. Influence of Warm Vertical Compaction Technique on Physical Properties of Root Canal Sealers. J Endod. 2016; 42 (12):1829-33.

63. Camilleri J. Sealers and warm gutta-percha obturation techniques. J Endod. 2015; 41 (1): 72-8.

64. Çelik Ünal G., Üreyen Kaya B., Taç A. G., Keçeci A. D. A comparison of the efficacy of conventional and new retreatment instruments to remove gutta-percha in curved root canals: An ex vivo study. Int Endod J. 2009; 42 (4): 344-50.

65. Roggendorf M. J., Legner M., Ebert J., Fillery E., Frankenberger R., Friedman S. Micro-C. $\mathrm{T}$. evaluation of residual material in canals filled with Activ GP or GuttaFlow following removal with NiTi instruments. Int Endod J. 2010; 43 (3): 200-9.

66. Hassanloo A., Watson P., Finer Y., Friedman S. Retreatment efficacy of the Epiphany soft resin obturation system. Int Endod J. 2007; 40 (8): 633-43.

67. Rödig T., Hausdörfer T., Konietschke F., Dullin C., Hahn W., Hülsmann M. Efficacy of D-RaCe and ProTaper Universal Retreatment NiTi instruments and hand files in removing gutta-percha from curved root canals - a micro-computed tomography study. Int Endod J. 2012; 45 (6): 580-9.

68. Ng Y-L, Mann V., Gulabivala K. Aprospective study of the factors affecting outcomes of nonsurgical root canal treatment: part 2: tooth survival. Int Endod J. 2011; 44 (7): 610-25. 